\title{
Governing Tourism Destination with Innovation System in Malang Regency
}

\author{
Nanda Dwi Meylani ${ }^{*}$, Kusdi Dea, Yusri Abdillah \\ Department of Business Administration, Faculty of Administrative Science, Universityof Brawijaya, Malang, Indonesia
}

\section{Abstract}

This research is a descriptive qualitative research that seeks to obtain a new perspective and describe tourism destination governance based on the innovation system in tourism in Malang Regency. The types of data in this study are primary data and secondary data. The researcher collected data using interviews, observation, and documentation. Data is analyzed by carried out throughout the research process, including the preparation of data management and data collection. The conclusion is carried out continuously by looking for patterns, themes, relationships, explanations, and causal paths regarding the results of research on tourism destination governance. The results indicate several problems that must be solved, such as the lack of tourism promotion, the lack of community involvement, limited material for tourism exhibition, and mismatch in tourism development. To solve the problems, the government must strengthen SIDa (Regional Innovation System), which consists of a strategic pillar and policy framework.

Keywords: governance, innovation systems, tourism destinations.

\section{INTRODUCTION}

Tourism has developed as a prominent industry around the world, and it has grown significantly in recent years. Each country competes to build and develop a tourism destination, which improves the tourists visitation. Some attempts have been done to encourage and enhance the quality of tourism destination management and competition. Tourism development is not only the task of government but also the duty of society. Society as a community is a pivot determinant to develop tourism. It presents that tourism stakeholder has enormous contribution to reach the goals of tourism development dan it can never be optimal without the support of tourism attraction management or party that has the authority of tourism development management $[1,2,3]$.

Tourism development aims to govern resources and create value-added wisely, integrated, holistic, and systemic to increase experience, sustainable value, and benefit for society. Indonesia has a strong tourist attraction, and it is very potential to be more developed. It has proof of increasing international tourists and local tourists significantly. Tourism in Indonesia has already become a development priority sector in 2017 after food, energy, and maritime. Development in the tourism sector, as well as progress in another area, requires involvement from many parties in an integrated form to increase social welfare. It must take an

\footnotetext{
*Correspondence address:

Nanda Dwi Meylani

Email : meilanynanda37@gmail.com

Address : Department of Business Administration, University of Brawijaya, M.T Haryono 169, Malang 65145
}

awareness that tourism is borderless, mainly at activity, space, and regional areas, so it is essential to govern tourism well.

In Indonesia, collaborative governance in tourism still has experienced many forms of hampering factors because of its lack of tourism actor synergy, including the public sector, which has a role in developing tourism. Collaboration has a vital function in reaching development goals; it is a system that connects each other. Collaboration with synergy includes Penta helix collaboration; they are academia, business, government, community, and media. In every single destination have to prepare decent attraction, amenity, and accessibility, promotion, and human resources. The main attraction is developed by business and community. Amenity is designed by industry and government, mainly the ministry of public work and housing. Accessibility is produced by the Ministry of Transportation, and the Ministry of Public Works and Housing. Tourism marketing depends on mass media; the quantity and quality of human resources depend on academia. The target which determined by the ministry of tourism is 20 billion international tourist and 275 billion local tourists in 2019.

Collaborative governance is vital in Indonesia Incorporated. It means that every institution, both public and private, that related to a particular goal, can exchange information, share resources, carry out their respective roles in synergy, and share risks, responsibilities, and only if they occur quality continuous communication. Components of the main actors that drive the wheels of tourism development are business/industrial actors, communities and communities, mass media, academics, and the 
government. In this case, the government plays a role as a facilitator, while the business/industry and the community (community, academics, and mass media) are the direct partners of tourism activities.

The principle of implementing good tourism governance, in essence, is the coordination and synchronization between existing stakeholders and active participation that is synergistic, integrated, and mutually reinforcing among tourism stakeholders through Penta Helix (government, business, academia, media, and the community). The management of tourism destinations in the Malang district has several obstacles, one of which is the weakness in the accuracy of tourism data collection comprehensively, especially about the development of tourism potential. Lack of education and technical training of tourism both for human resources as a manager as well as the readiness of society to be involved in tourism also feed one obstacle to unite tourism development programs with managers of other tourist destinations. The Innovation System is an institutional network and interaction in both the public and private sectors to initiate, import, modify, and diffuse new technologies [4].

Another obstacle faced by Malang Regency is the low absorption of technology and knowledge that supports tourism. Malang Regency does not yet have an integrated and comprehensive tourism potential portal that can invite tourists and investors. Focusing on innovative activities can be an option by building efficient networks to other destinations that can contribute to the exchange of information and knowledge. Therefore, destinations need to be recognized by the importance of knowledge management and implementation of systems such as, for example, expertise in databases that might be useful for securing information and knowledge and used to promote innovation activities. Several pieces of research explored tourism in Malang, for instance, promotion strategy [5], Agrotourism [6], the impact of tourism on Malang regional economics [7], and the role of the volunteer in ecotourism [8]. It is still a lack of governance and innovation research improving tourism in Malang Regency. Therefore the research aims to describe the governance based on the innovation system in Malang regency.

\section{Tourism Destination Governance}

Tourism destination is a fundamental factor that encourages tourists to visit some places; the places visited because it has appeal (attractiveness), facilities (amenities), and access (access). A tourist destination must meet the requirements to attract tourists. It has a unique attraction, and it has the appeal to be seen (something to see) $[2,9]$. It includes whether in the form of tourist attractions or entertainment. It has a vehicle or place or facility that can be used by tourists on tour (something to do) and feel at home for a more extended stay. It also provides facilities for shopping (something to buy), both in the form of souvenirs, special foods, etc. that can be used as souvenirs for tourists visiting there.

The destination is a physical currency of a local tourist destination where visitors shortly spend at least one night. It includes products and tourist attractions during a one-day trip home, which has physical and administrative boundaries by covering management, image, and perception on the market competitiveness. Then it merges various stakeholders, including communities, significant associations, and networks for broader purposes [10].

The view of governance in tourism destinations is primarily aimed at understanding market trends and phenomena, changing the management environment of resource capacity, locality capacity, and ecosystem. Tourism destination governance is a series of actions and efforts to increase the size of tourism destinations. It started from careful planning to consistent implementation and cautious control to optimize attractiveness, accessibility, facilities, and the community in the context of ecological, social, and community economy acquisition [10].

Corporate governance in the context of corporate governance is the set of processes, customs, policies, rules, and institutions that affect the direction, management and control of a company or corporation, which includes relationships between stakeholders involved in the management of the company [11]. Stakeholders in destination governance are shareholders, employees, suppliers, tourists, banks, creditors, regulators, the environment, and the community.

Tourism destination governance, based on an innovation system, will bring innovation as an essential component in economic renewal. Innovation is a process that must get a lot of support and attention. The governance view of innovation systems more explicitly brings the role of knowledge into an institution. Components or actors in innovation can consist of individual 
companies, public authorities, and agencies in education, research, and development $[4,12,13]$. The innovation system is by defining multi-actor structures. A distinctive element of innovation systems is the infrastructure of innovation, including research and renewal of science [14]. The functioning of a system lies in the relationship and ability to create actions and interactions that support collective performance that is beneficial to the actors and the community to develop various synergies and real solutions. In the end, the performance of the innovation system must be associated with effectiveness in generating, disseminating, and exploiting the knowledge that has economic benefits [4].

\section{MATERIAL AND METHOD \\ Study Area}

The research is descriptive research with a qualitative approach method [14]. The researchers try to obtain a new view of a phenomenon and describe clearly and deeply about tourism destination governance. Then the researchers deepen on the innovation system in tourism. The focus of this study is to examine the social phenomena that occur or are taking place in an area, especially in Malang Regency, about the governance of tourism destinations.

The research is located in Malang Regency, East Java. The area still has a problem with how to govern a tourism destination. The researchers made some contacts with the Department of Tourism as the manager of the management of tourism destinations in Malang Regency and Bappeda in Malang Regency as the planning body. Tourism destinations in Malang Regency have great potential in the development of tourism but have problems in the management of their destination. As an observation, researchers observed tourist destinations in Pujon Kidul is one of the tourism destinations that are considered the most capable of collaborating with their stakeholders by stimulating the economy of their communities. Researchers also observed tourist destinations in Poncokusumo, which is a pilot project for Regional Agro-tourism Innovation Systems in Malang Regency.

\section{Data Collection}

This study used primary data and secondary data. Researches applied interviews to obtain primary data, to several informants, which refers to the qualitative method based on genuine expression from the people [14]. Researches interviewed several key informants, they are 1) the Head of Tourism and Culture; 2) Head of Tourism Destination Development Division; 3) Head of Destination Management and Community Empowerment Section of Malang Regency; 4) Head of Planning, Infrastructure, and Regional Development Planning; 5) Head of SubDivision of Natural Resources Planning, Environment, and Water Resources in the Regional Planning and Development Agency of Malang Regency.

Secondary data were obtained from the tourist destination planning report of Malang Regency, Malang Regency District innovation system planning, and other supporting data. Data collection techniques in this study were interviews, observation, and documentation. The research instrument used in this study was the researchers themselves as observers, interview guidelines, and field notes.

\section{Data Analysis}

Testing the validity of the data, standard validation (validity), and reliability (reliability) refers to the validity of the construct data relating to the certainty that what is measured is the variable to be measured, namely the governance of tourism destinations in Malang Regency. The validity of this data is also achieved by the triangulation process, namely data triangulation, observer triangulation, and triangulation theory.

Data analysis in this study was carried out from the beginning and throughout the research process took place with two main steps, namely compiling data management and collecting data [15]. Drawing conclusions in this research is carried out continuously by looking for patterns, themes, relations of equations, explanations, and causal paths (reduction process) regarding the results of research on tourism destination governance and then poured in the form of temporary conclusions.

\section{RESULT AND DISCUSSION}

The researcher found several problems in governing tourism destination with the innovation system in Malang regency. After analyzed the problem, we proposed an idea to cope with the problems.

\section{The Lack of Tourism Promotion}

Tourism promotion is not optimal, mainly in the international scope, in this case. It is essential to solving such a problem because tourism promotion has a role in the perception of traveler and formation of image destination [16]. The 
promotion must do with exhibitions, mass media, and electronic media/IT. The promotion will enhance success if there is an increase in domestic and international tourists.

\section{Lack of Community Involvement}

In this case, the community does not get much involvement in developing tourism destinations. The local government should initiate empowerment for the local community. The model of community-based tourism, which involve several parts of participation, should be proposed; it might lead to bringing more benefit to the community as well the business $[17,18,19]$. The more active community will be represented by the amount of local group which gets involved in developing local tourism destination such as micro, small, and medium enterprises.

\section{Data Inaccuracy}

Lack of data inaccuracy creates loopholes in decision making, mainly in this case, the data which relate to tourism destination potential. Reliable data in tourism, such as sound policies and efficient managerial decisions, will provide a more accurate forecast [20]. Therefore the government must create knowledge management that provides data banks such as grand design for developing local tourism potential and local enterprise registration.

\section{Limited Material For Tourism Exhibition}

Many materials for tourism exhibition in Malang regency has a limited source primarily when the tourism provider does not show their unique product in the exhibition. Exhibition tourism has generated direct and indirect economic impacts [21]. The government must coordinate will tourism providers and make reliable data for their unique products.

\section{Mismatch in Tourism Development}

The development of tourism destinations does not work well because many institutions go for their vested interest. Regional development involves optimizing the utilization of the region's resources in an integrated and harmonious way. This regional development realized through a comprehensive approach that includes physical, economic, social, cultural, and environmental aspects [22]. The government should increase the coordination function to run a better plan and execution in one management. It will be seen as an increasing number of infrastructure projects and cooperation around different organizations.

\section{SIDa Strengthening Pillar}

The strategy used to solve problems using SIDa (Regional Innovation System/Sistem Inovasi Daerah). It was developed from the strategic pillars of improving the innovation system which consisted ofthe following (Fig. 1).The findings relate to the research that SIDa will be significant if there are strong commitment and political will within the stakeholder [23].

1) SIDa strengthening initiatives were aimed at improving the pillars for the development of innovations at the regional level, which are an integral part of strengthening the national innovation system. It was also to build an ecosystem for the development of innovation and business in accordance with the objective.

2) Development of Industrial Clusters aims to develop the best potential of the economic sector and improve industrial competitivenessin accordance with the objectives.

3) Development of innovation networks is a vehicle for building linkages and partnerships between actors and dynamizing the flow of knowledge, innovation, diffusion, and learning in accordance with the objectives.

4) Technopreneur development as a vehicle for business/economic, social, and cultural development modernization in accordance with the goals to be performed.

5) Development of thematic pillars policy, which aims to improve elements of the system strengthening thematic and contextual conformity with the objectives.

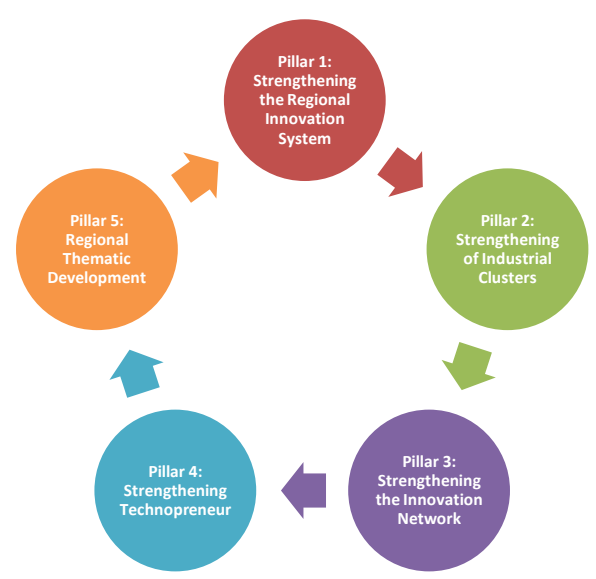

Figure 1. SIDa Strenghtening Pillar

The next step must be a need to make a focus policy framework and never forget the integration as well [24]. The focus of SIDa strengthening is a detailed description of each 
element of the Innovation Policy Framework, which includes six keypoints.

First, focus on developing a general framework conducive to the development of innovation and business. It includes the development of innovation and business database, development of helpful regulations, the amount of investment in the information technology, improvement of public services, government procurement that is a pro-innovative business, development of fundamental innovation and business infrastructure, and providing incentives for innovation and industry.

Second, focus on institutional strengthening and supporting the capacity of information and technology or research and development, and develop micro, small, and medium enterprises absorption capabilities. It consisted of the development and enhancement of institutions, development of information and technology support capacity, and development of micro, small, and medium enterprises absorption power.

Third, the focus of collaborative development is on innovation and increasing the diffusion of innovations, best practices, and results of the field. It includes the development/strengthening of cooperative institutions, increased diffusion of innovations, ethical practices, and results of wealth, and development/strengthening of technology-based services.

Fourth, the focus is on encouraging a culture of innovation. This key point includes the development/strengthening of innovation culture through education and innovation training channels, strengthening of social cohesion, increasing community participation in innovative creativity, development of innovation appreciation and campaigns, and the creation of innovative new ventures.

Fifth, the focus of development and strengthening of integration/coherence in advancing innovation systems in the regions.It includes strengthening/developing integrated innovation system initiatives, growth/enhancing coordination of national and regional policies, and special institutional development/ strengthening.

Sixth, focus on aligning with global developments. The key pointincludesthe development of environmental sustainability or innovation/green technology initiatives; development/strengthening of the application of measurement, standardization, testing, and quality assurance (measurement, standardiza- tion, testing, and quality assurance; development of utilization of Intellectual Property Right (IPR); increasing awareness of issues and alignment with relevant international dynamics (such as employment, human rights, etc.); and development of regional branding and/or regional global position.

Table 1. Keypoints of Policy Frameworkfor SIDA Strenghtening

\begin{tabular}{ll}
\hline No. & \multicolumn{1}{c}{ Keypoints } \\
\hline 1. & $\begin{array}{l}\text { Focus on developing a general framework which is } \\
\text { conducive to the development of innovation and } \\
\text { business. }\end{array}$ \\
2. & $\begin{array}{l}\text { Focus on institutional strengthening and } \\
\text { supporting the capacity of information and } \\
\text { technology or research and development and } \\
\text { develop micro, small, and medium enterprises' } \\
\text { absorption capabilities. }\end{array}$ \\
3. & $\begin{array}{l}\text { Focus on the collaborative development of } \\
\text { innovation and increasing the diffusion of } \\
\text { innovations, best practices, and results of the } \\
\text { field. } \\
\text { Focus on encouraging a culture of innovation. } \\
\text { 5. Focus on the development and strengthening of } \\
\text { integration/coherence in advancing innovation } \\
\text { systems in the regions. } \\
\text { Focus on aligning with global developments. }\end{array}$ \\
\hline
\end{tabular}

\section{CONCLUSION}

A regional development program is a set of priority programs that are specifically related to the achievement of regional development targets. A regional development at least contains a program of the elected Regional Head which provides strategic priority programs that have been formulated based on general policies and required performance indicators (outcomes).

The results indicate several problems that must be solved, such as the lack of tourism promotion, the lack of community involvement, limited material for tourism exhibition, and mismatch in tourism development. To solve the problems, the government must strengthen SIDa (Regional Innovation System), which consists of a strategic pillar and policy framework.It is expected that all Regional Office will support the programs and activities, to realize superior regions in Malang Regency, which can compete nationally and internationally.

\section{REFERENCES}

[1] Affyn, A. 2000. Developing sustainable tourism in the Trossachs, Scotland. In: Richards, G. and D. Hall (Eds). Tourism and Sustainable Community Development. Routledge. London. 
[2] Hakim, L. 2004. Dasar-dasar ekowisata. Bayumedia. Malang.

[3] Touhino, A. and H. Konu. 2014. Local stakeholders' view about destination management: who are leading tourism development?. Tourism Review 69(3), 202215.

[4] Lundvall, B. 1992. National System of Innovation Towards a Theory of innovation and interactive learning. Pinter Publisher. London.

[5] Nuansa, C., Suryadi, and D.Wisadirana. 2014. Designing promotion strategy of Malang Raya's tourism destination branding through audio visual media. Journal of Indonesian Tourism and Development Studies 2(2),82-85.

[6] Pangestuti, E., L. Hanum, and L. E.Wahyudi. 2018. Development of agrotourism in Kampung Kopi Amadanom, Malang. Journal of Indonesian Tourism and Development Studies 6(3), 194-199.

[7] Wahyuni, E. T., Susilo, S. Muljaningsih. 2018. Regional economics: how does tourism influence regional revenue of Malang Raya? Journal of Indonesian Tourism and Development Studies 6(2), 93-102.

[8] Wibowo, F. A. A., H. Riniwati and I. Nugroho. 2018. The role of volunteer for the management of conservation-based ecotourism in Clungup Mangrove Conservation Tambakrejo Village, Sumbermanjing Wetan Sub-District, Malang. Journal of Indonesian Tourism and Development Studies 6(3), 187-193.

[9] Sunaryo, B. 2013. Kebijakan pembangunan destinasi pariwisata konsep dan aplikasinya di Indonesia. Gava Media.Yogyakarta.

[10] World Tourism Organizaion. UNWTO Tourism Highlights, 2004 Edition.United Nations World Tourism Organizaion. Madrid, DOI: https://doi.org/10.18111/97892844079 10.

[11] Teguh, F. 2015. Tata kelola destinasi membangun ekosistem pariwisata. Gadjah Mada University Press. Yogyakarta.

[12] Colley, J. W. Stettinius, J. Doyle, and G. Logan. 2004. What is corporate governance? McGraw-Hill. New York.

[13] Freeman, L.C. 1979. Centrality in social networks: I. Conceptual clarifications. Social Networks 1, 215-239.

[14] Bungin, B. (Ed). 2017. Metodologi penelitian kualitatif: aktualisasi metodologis ke arah varian kontemporer. Rajagrafindo Persada. Jakarta.

[15] Miles, M. B. and A. M. Huberman. 1999. Analisisdata kualitatif. Revised Ed. University of Indonesia Press. Jakarta.

[16] Spilling, O. R. 1998. Beyond intermezzo? on the long-term industrial impacts of megaevents: the case of Lillehammer 1994. Festival management and event tourism. 5(3), 101-122.

[17] Govers, R., F. M. Go, and K. Kumar. 2007. Promoting tourism destination image. Journal of Travel Research 46(1). DOI: 10.1177/0047287507302374.

[18] Hakim, L., and M. Soemarno. 2017. Biodiversity conservation, community development and geotourism development in bromo-tengger-semeru-arjuno biosphere reserve. Geojournal of Tourism and Geosites 20(2), 220-230.

[19] Purmada, D. K., and L. Hakim. 2016. Pengelolaan desa wisata dalam perspektif community based tourism (studi kasus pada Desa Wisata Gubugklakah, Kecamatan Poncokusumo, Kabupaten Malang). Jurnal Administrasi Bisnis 32(2), 15-22.

[20] Moyo, S. and T. M. Tichawa. 2017. Community involvement and participation in tourism development: a Zimbabwe Study. African Journal of Hospitality, Tourism and Leisure 6(1), 1-15.

[21] Kim, N. And Z. Schawrtz. 2013. The accuracy of tourism forecasting and data characteristics: a meta-analytical approach. Journal of Hospitality Marketing and Management 22(4), 349-374.

[22] Widhianthini. 2017. A dynamic model for sustainable tourism village planning based on local institutions. Journal of Regional and City Planning 28(1), 1-15.

[23] Carlsen, J. 1999. A review of MICE industry evaluation and research in Asia and Australia 1988-1998. Journal of Convention and Exhibition Management 1(4), 51-67.

[24] Tucunan, K. P., A. Pamungkas, H. Idajati, J. Krisdianto, and D. A. Ardianta. 2015. Tourism Innovation System (SIDA) in Pringgabaya based on sea waves energy development initiative. Procedia - Social and Behavioral Sciences 227, 680-685. 